\title{
The appreciation of nature and landscape by tourism service providers and visitors in the Ore Mountains (Germany)
}

\author{
Olaf Bastian ${ }_{1}^{*}$, Christian Stein $_{2}$, Gerd Lupp $_{3^{\prime}}$, Jan Behrens ${ }_{4}$, Christina Renner ${ }_{5}$, Karsten \\ Grunewald $_{2}$ \\ 1 State Capital of Dresden, Environmental Authority, P.O. Box 1200 20, D-01001 Dresden, Germany \\ 2 Leibniz Institute of Ecological Urban and Regional Development, Weberplatz 1, D-01217 Dresden, Germany \\ 3 Chair for Strategic Landscape Planning and Management, TU Munich, Emil-Ramann-Str. 6, 85354 Freising, Germany \\ 4 Technische Universität Dresden, Chair of Tourism Economics and Management, D-01062 Dresden, Germany \\ 5 Alaunstr. 90, D-01099 Dresden, Germany
}

\begin{abstract}
The paper presents empirical studies on the appreciation of nature and landscape in the Eastern Ore Mountains (Saxony, Germany) by tourism service providers (TSP) and visitors. Attractive landscape and experience of nature are the most important reasons to visit this region and to spend leisure time there. Particularly mountain meadows, raised bogs and mixed forests are highly appreciated. Deforestation, industrial development and the decline of biodiversity would reduce attractiveness for visitors. We also assessed whether the tourism sector is prepared to contribute to the funding of nature conservation and landscape management. Use of general tax revenues is favoured, but other modes would also be accepted, e.g. a nature tax. Willingness to pay (WTP) is ranging between $€ 0.75$ and $€ 1.36$ per guest per night by TSP, or between $€ 1.06$ and $€ 2.73$ per day by visitors. With respect to landscape preference and WTP we found in some cases significant differences among visitors, depending on region of residence, age and education level. A major part of the annual costs for nature conservation and landscape could be covered by public funds (taxes), if the results of the WTP approach were understood as a sign of societal demand and a call to action.
\end{abstract}

\section{Keywords:}

Landscape attractiveness; landscape management; nature tax; stated preference valuation; ecosystem services; willingness to pay

\footnotetext{
*Corresponding author. Email: Olaf.Bastian@web.de

(C) The Authors. 2015. Landscape Online. This is an Open Access article distributed under the terms of the Creative Commons Attribution License (http://creativecommons.org/licenses/by/4.0), which permits unrestricted use, distribution, and reproduction in any medium, provided the original work is properly cited.
} 


\section{Introduction}

T he concept of ecosystem services comprises both the supply of services, which is based on the structures, processes and potentials of ecosystems and landscapes, and the demand for these services by particular beneficiaries, stakeholder groups or society as a whole. To date, the ranking of services by beneficiaries has received only limited attention (Lamarque et al. 2011; Seppelt et al. 2012). Hence, there is a need for additional research on the demand for and supply of ecosystem services, rather than for a focus on supply alone (Termorshuizen \& Opdam 2009; García-Nieto et al. 2013). Also Honey-Rosés \& Pendleton (2013) note that "better information about ecological processes or abstract valuations will not spur better decision-making", and that "despite a large and growing body of studies on the supply of ecosystem services, ecosystem services thinking and information is still not being used by the decision makers who need it."

While there is a general broad social consensus for the permanent preservation and development of valuable landscapes with their ecosystems, and numerous studies on willingness to provide the financial means to do this exist (e.g. Spangenberg \& Settele 2010; Grunewald et al. 2014), it is difficult to achieve consensus on the specific development direction in an area (Lupp et al. 2014) - e.g. in a tourist region - and the preferred or the most favorable management options. Demand driven analyses of the public may support politicians and planners to design management policies and to set priorities in regard where to invest public money to maintain landscapes and protect biodiversity and gain acceptance (e.g. Casado-Arznaga et al. 2013).

Nature conservation, especially the maintenance of human-influenced, biodiversity-rich, so-called seminatural ecosystems, e.g. the flowering mountain meadows which may shape the character of many cultural landscapes or tourist regions attracting especially nature-oriented tourists need considerable financial means. Such analyses should be also seen against the background of the further development of existing and the establishment of new funding models involving tourism to mobilize financial sources for landscape management (Heuchele et al. 2014).

The social expenditures and costs for landscape management society is ready to bear, represent an indicator of the economic valuation of ecosystems, since the existence of some cultural landscape ecosystems is closely linked to permanent human intervention in the form of specific land use or management measures (Farber et al. 2006; Grunewald et al. 2014).

Nature and natural landscapes are key elements of numerous recreation and tourism forms. They range from active nature experiences (e.g. wildlife watching) to more hedonistic activities with natural features as backdrop (e.g. skiing, hunting or fishing, combined culture/nature trips) (Strasdas 2006; Arnegger et al. 2010; Coghlan \& Buckley 2013). Nature-based tourism is "marked by a desire to spend time in places and spaces (...) that provide meaningful, transformative, spontaneous and extraordinaryexperiences" (Curtin 2013). Ecotourism can be seen as a special subset of nature(-based) tourism conserving the environment and improving the well-being of local people (TIES 1990), and thus as a special manifestation of sustainable tourism.

A nationwide representative survey of nature awareness in Germany reveals that a vast majority of people places high value on nature in terms of quality of life, health and recreation (BMU \& BfN 2014). For more than half of all Germans, "experiencing nature" is a key motivation for holidays (FUR 2013). Domestic tourists in Germany regard beautiful nature and a good price-performance ratio as most important aspects for their personal happiness during their holidays; this is particularly distinctive in the age group of 65 years or more (SfZ 2014). Three-quarters of German holidaymakers feel psychologically deterred by obstructed landscapes that have lost their pristine character (Kösterke \& von Laßberg 2005). Therefore, opportunities to experience nature often represent decisive factors within the selection process of holiday destinations (Kösterke \& von Laßberg 2005; Pröbstl-Haider \& Haider 2014). 
Due to their attractive landscapes and wildlife as well as their cultural attractions mountainous regions around the world are important destinations for recreation and tourism (Fredman \& Lindberg 2008; Beza 2010; Pickering \& Barros 2013). In Germany, the Alps and several low mountain ranges offer various opportunities for outdoor activities like hiking, trekking, mountain biking or skiing (BMWi 2013).

This paper presents questionnaire-based empirical studies on the appreciation of nature, semi-natural and natural ecosystems, landscape elements, landscape qualities and ecosystem services in the Eastern Ore Mountains in the German state of Saxony, by different stakeholder groups: tourism service providers (TSP) and visitors (tourists with overnight stays and same-day visitors). Also the role of landscape changes on the visitor behaviour is addressed. Moreover, it examines the question as to whether these groups are prepared to participate in the costs for nature conservation and landscape management in the region, and which funding models for nature conservation are favoured. It is also investigated whether appreciation of nature and the landscape, and the willingness to pay (WTP), correlate with socio-demographic data (e.g. place of residence, age, level of education, lifestyle).

\section{Methods}

\subsection{General remarks}

The supply side of ecosystem services (ecosystem properties and potentials - Bastian et al. 2012) can be analyzed with classical (landscape) ecological methods. It has been carried out already for a wide spectrum of provisioning, regulation and socio-cultural services in the Ore Mountains on the example of Natura 2000 sites (Bastian et al. 2010; Bastian 2013) and is not in the focus here. For the assessment of the demand side, we designed standardized questionnaires, one for TSP (see chapter 2.3) and one for visitors (outdoor recreationists) (see chapter 2.4).
The study deploys the contingent valuation method in order to assess the willingness to pay of TSP and visitors for conservation purposes. Stated preference analyses like the contingent valuation method or choice experiments do not only reveal the amount that people would be prepared to pay, but also the conditions or developments in the environment which they desire, or want to avoid. On the basis of the results of such assessments, it is then possible to determine the actions and the limits required to avoid deteriorations (Grunewald et al. 2012).

Thus, the contingent valuation method is frequently applied to determine the appreciation of visitors for particular qualities of nature and landscape (Lee \& Han 2002; Tisdell 2006), referring to recreational and other non-material benefits of ecosystem services like aesthetic pleasure, spiritual values or educational purposes (Butler \& Oluoch-Kosura 2006). This method can also be used to estimate nonuse values in monetary terms like existence values of natural attributes (for example wildlife species) or bequest values, reflecting individual attitudes towards conservation efforts for future generations (Tisdell 2006; Mayer \& Job 2014).

Moreover, numerous scientific studies employ the contingent valuation method and other stated preference techniques to assess WTP with regard to user fees in relation to tourism and outdoor recreation activities in protected areas or other (non-protected) public natural areas (Mmopelwa et al. 2007; Reynisdottir et al. 2008; Rosenberger et al. 2012; Wang \& Jia 2012; Mayer 2014). Concerning the legitimacy of imposing entrance and other user fees on nature tourists a "user pays" principle aiming at contributions of tourists applies. This opposes a "public good" view that advocates public funding of nature conservation by general taxes (Reynisdottir et al. 2008). An alternative tourism-oriented approach is the imposition of special taxes dedicated to the management and conservation of natural areas (e.g. room tax, "nature tax") (Laarman \& Gregersen 1996; Degenhardt et al. 1998; Oom do Valle et al. 2012; Renner et al. 2012).

In recent years, a growing number of contingent studies have been undertaken world-wide, e.g. Degenhardt et al. (1998); Elsasser et al. (2009); 
Meyerhoff et al. (2010); Tacconi (2012). Barrio \& Loureiro (2010) presented a comprehensive review of contingent studies, and the pros and cons of such methods was discussed by Chee (2004) but also by Riera et al. (2012) who also developed a set of good practice guidelines for the non-market valuation (of forests), elaborating on stated and revealed preference methodologies.

\subsection{The study area}

The study area (Fig. 1) is situated in the German part of the Eastern Ore Mountains (the district Sächsische Schweiz-Osterzgebirge, in southern Saxony), in the rural municipalities of Altenberg (population: 8500), Hermsdorf (900), and Bad Gottleuba-Berggießhübel (6000). The average annual income in the district in 2012 was $€ 18,332$ per person (DESTATIS 2014).

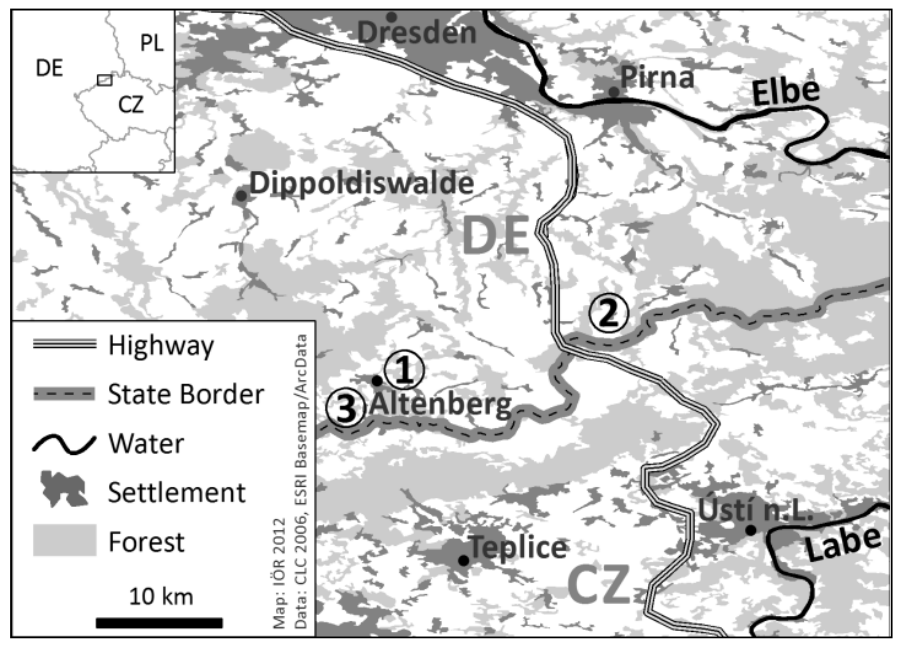

Figure 1: The Eastern Ore Mountains with the study sites Geisingberg meadows (1), Oelsen meadows (2) and the Georgenfeld raised bog (3)

The Ore Mountains (German Erzgebirge), a traditional cultural landscape of European significance particularly marked by ore mining, have the shape of a slanted desk of approx. $150 \mathrm{~km}$ in length, formed by tectonic forces. Acid rocks such as gneiss, phyllite and granite are typical for this mountain range. The harsh climate has given rise to such characteristic ecosystems as raised bogs and mountain meadows, with such anthropogenic features as stone walls, cairns and hedgerows (Fig. 2 and 3). Often, mixed mountain forests and streams are still in a state close to nature. The Ore Mountains ridge, which rises an average of 800-1000 $\mathrm{m}$ above sea level, also forms the border between Germany and the Czech Republic. Particularly this ridge zone features many valuable natural areas, and thus has a high attractiveness for nature-related tourism (Bastian et al. 2010; Bastian 2013). The land use pattern consists of forests (especially on the ridge), grassland, arable fields and settlements (villages, small towns).

\subsection{Survey of tourism service providers (TSP)}

In a first step, we analyzed TSP in the study area. Data banks provided by the communities like tourism catalogues were used to identify TSP. For the study, all TSP having e-mail addresses were selected. One disadvantage of this method was, that only those TSP being listed in an accommodation directory or with an own website and having e-mail were within the survey group. Thus, especially small size TSP and small private overnight stay providers like holiday apartments are probably underrepresented in this sample. The perception of the TSP in the study area was examined using an online survey conducted between April and May 2012. We first established an address database with the aid of an internet search in accommodation directories.

The survey was performed with the online questionnaire "oFb-der onlineFragebogen" on www. soscisurvey.de. The questionnaire was available only via a serial number, which was sent together with an e-mail to all the addresses in the database. This procedure ensured that the participants replied to the questionnaire only once, and that only the addressed target group was able to participate. The questionnaire was sent by e-mail to 223 recipients. After two weeks' time, we sent out a reminder to all recipients who had not yet returned the questionnaire.

\subsection{Survey of visitors}

For the survey of outdoor recreationists (see Blamey 2001; in the following we prefer the shorter term "visitor") in the area, we used similar questions (Table 1), slightly adapted for this target group. Here, we used on-site interviews with passers-by at well 
attended natural sites in typical ecosystems/nature reserves for the Ore Mountains: mountain meadows, which were in bloom during the survey period, at the mountain Geisingberg (Fig. 2), close to the town of Altenberg, easily accessible by public transportation; near the village of Oelsen, a remote scenic outlook accessible only by car; and the Georgenfeld raised bog, the only nature reserve in the Ore Mountains, where visitors have to pay an entrance fee to walk along the nature trail (Fig. 3).

Before the final survey we had conducted pre-tests to adjust the questionnaire to ensure that it is well understood and correctly worded, and that (only) the

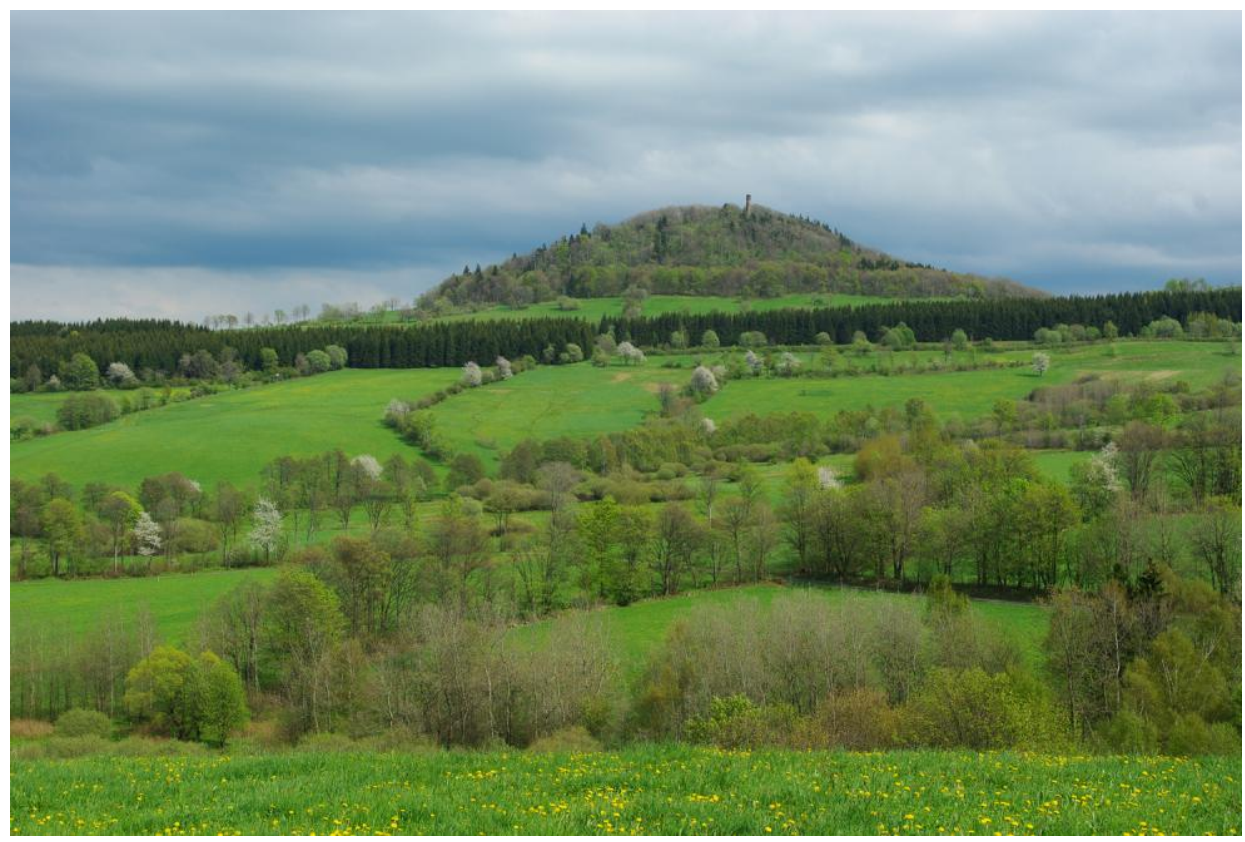

Figure 2: Typical landscape of the Eastern Ore Mountains near the Geisingberg mountain with mountain meadows and stone walls (photo O. Bastian)

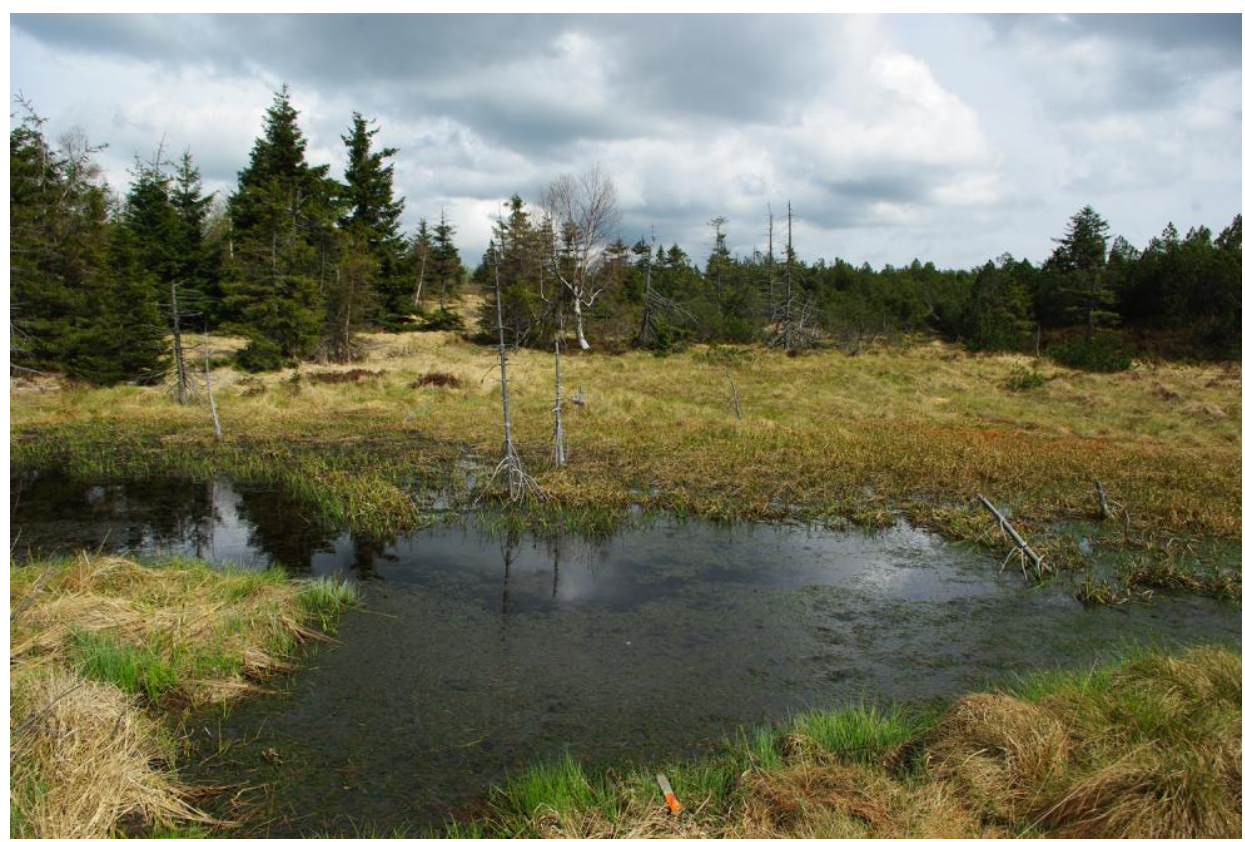

Figure 3: The Georgenfeld raised bog - view from the nature trail (photo 0. Bastian) 
most important questions are included. The survey was performed between the end of May and the end of June 2012, mainly on weekends and during the Whitsun holiday, so as to reach many visitors. Questioning started at 10:00 a.m. and ended around 5:00 p.m. Passers-by were approached at random and asked to participate in the survey. We expected this approach would provide us with more answers and more reliable information than by sending letters or displaying questionnaires at hotels or other accommodation places.

\subsection{Structure of the questionnaires}

The questionnaires comprised between 13 and 20 questions: The introductory part asked for the reason and the character of the visit. The two main parts dealt with the appreciation of nature and the landscape (elements), and with the importance and funding of nature conservation and landscape management (Table 1). Finally, socio-demographic data was collected (only in the questionnaires for visitors). The questionnaires were designed not to require more than 15 to 20 minutes to be answered. We felt it wise to ask partly different questions to tourism service providers (TSP) and visitors. In general, the first group is more competent in tourism as a whole, while individual visitors express their opinions from other points of view.

We applied different forms of questions: mainly closed questions, some semi-open, and a few open ended questions (e.g. Degenhardt et al. 1998, Atteslander 2010). In some cases, we asked persons to rate items on a Likert scale from 1 to 5 (e.g., 1 = not important/not attractive ... 5 = very important/ very attractive). Multiple answers were allowed in most cases.

Table 1: Main content of questionnaires for the survey of tourism service providers (TSP) and visitors in the Eastern Ore Mountains

\begin{tabular}{|l|l|l|}
\hline Question & Survey group \\
\cline { 2 - 4 } & TSP & Visitors \\
\hline What are the main motivations for visiting the Eastern Ore Mountains? & $\mathrm{x}$ & $\mathrm{x}$ \\
\hline What are the favoured leisure activities exercised here? & $\mathrm{x}$ & \\
\hline Which landscape elements are found especially attractive? & $\mathrm{x}$ & $\mathrm{x}$ \\
\hline In which manner landscape changes influence visiting behaviour? & $\mathrm{x}$ & $\mathrm{x}$ \\
\hline Which importance is attached to particular ecosystem services? & & $\mathrm{x}$ \\
\hline $\begin{array}{l}\text { What is the role of protected areas for the tourist attractiveness of the } \\
\text { region? }\end{array}$ & $\mathrm{x}$ & \\
\hline $\begin{array}{l}\text { Do you know any protected area in the region and the Natura 2000 } \\
\text { system? }\end{array}$ & $\mathrm{x}$ & \\
\hline $\begin{array}{l}\text { Do you think landscape management is necessary, and if yes, for what } \\
\text { reasons? }\end{array}$ & $\mathrm{x}$ & $\mathrm{x}$ \\
\hline $\begin{array}{l}\text { Who should be responsible for funding nature conservation (and } \\
\text { landscape management)? }\end{array}$ & $\mathrm{x}$ & $\mathrm{x}$ \\
\hline $\begin{array}{l}\text { Do you think that tourism should contribute to nature conservation by } \\
\text { financial means? }\end{array}$ & $\mathrm{x}$ & \\
\hline $\begin{array}{l}\text { Would you be ready to support nature conservation by own financial } \\
\text { means? }\end{array}$ & $\mathrm{x}$ & $\mathrm{x}$ \\
\hline What is the height of payments you would accept? & $\mathrm{x}$ & $\mathrm{x}$ \\
\hline $\begin{array}{l}\text { Do you think that the introduction of a nature tax in the Eastern Ore } \\
\text { Mountains is justified and feasible? }\end{array}$ & $\mathrm{x}$ & $\mathrm{x}$ \\
\hline Who should receive these payments? & $\mathrm{x}$ & \\
\hline
\end{tabular}


Questions concerning the monetary value (WTP) we formulated differently. On the one hand, we asked for the maximum amount the respondent is prepared to pay (open question). On the other, we wanted to know whether the respondent was prepared to pay a predefined amount of money (closed question: agreement or disagreement).

The tourism sector profits from the management and restoration of habitats and ecosystems, because landscape attractiveness is enhanced. Therefore, we inquired whether and to which extent the tourism sector would be prepared and able to contribute to the funding of such management, and whether the costs of nature conservation and landscape management are justified from the point of view of tourism. We presented a filter question to the TSP concerning their willingness to provide financial contributions. If they answered "no", only one additional question followed regarding the reasons of the denial, and the survey was concluded. In order to estimate the amount of a possible financial contribution of the tourism sector or to quantify the WTP, the TSP were asked to measure the amount of taxes per guests and night (in the form of an open question).

To detect possible discrepancies between different users, sub-groups were defined and compared using statistical tests $\left(\chi^{2}-, t\right.$-test): Residents of the district vs. external visitors; older ( $>40$ ) vs. younger persons (up to 40), and persons with higher education (university graduates) vs. those with lower education (secondary school, vocational training, etc). The latter two differentiations also enable application of a simple lifestyle group concept, according to the German sociologist Schulze (1997). Recent studies indicate that value orientation (Müller \& Job 2009; Lupp, et al. 2011) or lifestyles strongly affect opinions and attitudes towards the environment, and seem to provide a better differentiation and understanding than do such purely sociodemographic characteristics as age or gender (UBA, 2009).

\section{Results}

\subsection{Level and profiles of the respondents}

A total of 72 recipients among the tourism service providers (TSP) completed the questionnaire; the response rate was $32 \%$. This response rate is in line with the average response rate for questionnaires at the SoSci Panel (20\%) and other internet-based surveys (Cook et al. 2000). Of the TSP surveyed, $74 \%$ owned holiday accommodations; the others worked in restaurants, trade and such other tourism-related services as retailing, tour operating, or cultural facilities.

Table 2: Selected characteristics of surveyed visitors in the Eastern Ore Mountains

\begin{tabular}{|c|c|c|c|c|c|}
\hline Gender & $\begin{array}{r}\text { Male: } \\
\text { Female: }\end{array}$ & $\begin{array}{l}145 \\
157\end{array}$ & $\frac{\text { Duration }}{\text { of stay }}$ & $\begin{array}{r}\text { Day trip } \\
\text { Overnight stay }\end{array}$ & $\begin{array}{l}252 \\
56\end{array}$ \\
\hline Age & $\begin{array}{r}<18: \\
\text { 18-30: } \\
31-40: \\
41-50: \\
51-60: \\
>60:\end{array}$ & $\begin{array}{l}1 \\
18 \\
28 \\
72 \\
59 \\
125\end{array}$ & Origin & $\begin{array}{r}\text { Altenberg: } \\
\text { District of Sächsische } \\
\text { Schweiz-Osterzgebirge: } \\
\text { Saxony: } \\
\text { Germany: } \\
\text { Czech Republic: }\end{array}$ & $\begin{array}{l}17 \\
75 \\
179 \\
29 \\
2\end{array}$ \\
\hline$\frac{\text { Household }}{\text { income }}$ & $\begin{array}{r} \\
\quad \leq 1000 €: \\
\\
\leq 2000 €: \\
\leq 3000 €: \\
\leq 4000 €: \\
>4000 €: \\
\text { Not specified: }\end{array}$ & $\begin{array}{l}47 \\
92 \\
43 \\
15 \\
4 \\
81\end{array}$ & Education & $\begin{array}{r}\text { No qualification: } \\
\text { Vocational training: } \\
\text { A Level: } \\
\text { Secondary school: } \\
\text { Foreman: } \\
\text { University or college degree: }\end{array}$ & $\begin{array}{l}0 \\
75 \\
15 \\
14 \\
20 \\
169\end{array}$ \\
\hline
\end{tabular}


Of the 308 surveyed visitors (passers-by), 75 came from the district of Sächsische SchweizOsterzgebirge the study area is belonging to, and 210 came from outside but mostly from Saxony. By age, 256 (85\%) interviewees were older than 40 , many of them older than 60 . Most of the respondents visit the Eastern Ore Mountains and its natural highlights frequently. Of the respondents, $82 \%$ were on a day trip; the others stayed four days on average (Table 2).

\subsection{Appreciation of nature, landscape and ecosystem services}

The TSP emphasized - besides the good priceperformance ratio and the opportunity for sports (skiing) - the particularly attractive nature and landscape as the main reasons for tourists to visit the region, with $86 \%$ stating that their guests preferred to hike in nature. One third of the respondents mentioned that their guests liked to observe nature (plants, animals).

For the majority of surveyed visitors $(221=71.8 \%)$, experiencing nature was an important motivation for their visit (Fig. 4). Pair-wise comparisons (visitors from the district/from outside, younger/ older people, lower/higher education) showed no significant differences.

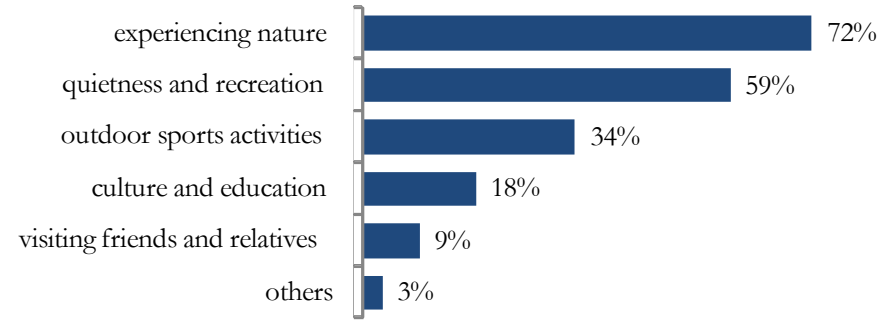

Figure 4: Motivation for recreation in the Eastern Ore Mountains (multiple responses), visitor survey $(n=308)$

Most TSP (60\%) attributed the highest attractiveness of landscape elements for tourists to the mountain meadows and mixed mountain forests, and to a slightly lesser degree, to running waters, raised bogs, stone walls/hedgerows and spruce forests. Particularly the management of mountain meadows was seen as important for tourism (average value of 4.5 on the Likert scale). Management of hedges and stone walls (value 4.0) and restructuring spruce forests to mixed stands (3.9) were also seen as important for tourism. Species protection received a slightly lower value (3.7).

The visitors surveyed attached the highest priority to maintaining mountain meadows (4.7), raised bogs (4.5), watercourses (4.4), mixed forests (4.3) and hedgerows (4.2). It is interesting that they valuate the importance of landscape elements higher than the TSP do (Fig. 5). The largest differences concern raised bogs and hedgerows/stone walls.

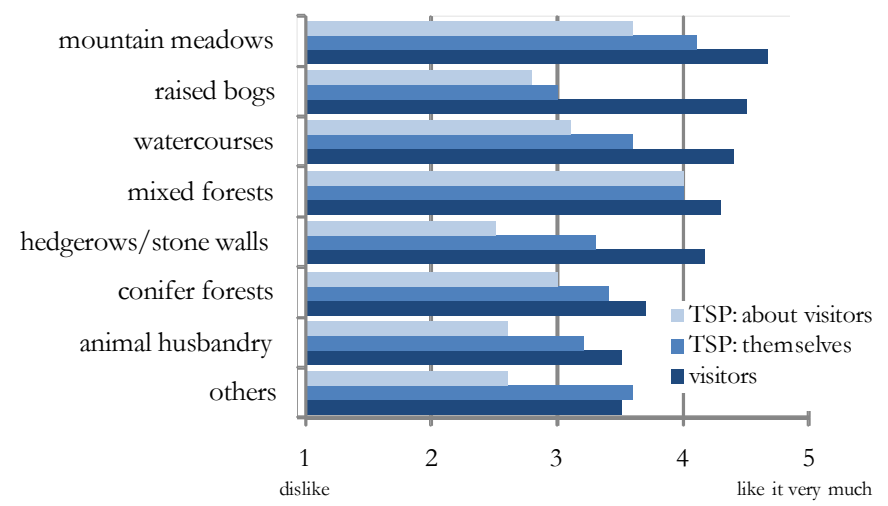

Figure 5: Valuation of different landscape elements in the Eastern Ore Mountains by visitors (visitors $n=308$; TSP $\mathrm{n}=66$ average values; 5 : like it very much; 1 : dislike)

While there are almost no significant differences between both groups of visitors (residents of the district/visitors from outside the district) in terms of ranking landscape elements, there are such differences with regard to age classes and educational levels (pairwise comparisons) for mountain meadows, with the assignment of a ranking of 5 (like it very much) as follows: older vs. younger: $82 \% / 60 \%$, and of a 1 (dislike): $12 \% / 26 \%$; for hedgerows and stone walls: older vs. younger: ranking of 5 : $53 \% / 31 \%$; of 1 : $23 \% / 36 \%$. Thus, mountain meadows and hedgerows/stone walls are more appreciated by older persons. People with lower education ranked conifer forests higher than did more highly educated persons (only weak significance), and they gave a higher priority to the maintenance of animal pasturing (cp. the higher appreciation of the less educated group for animal habitats - in this section, below). 
More than the half of TSP (53\%) believed that protected areas would enhance the attractiveness of the region and would contribute to the development of tourism; $21 \%$ stated that protected areas would not be attractive for tourists. $71 \%$ of TSP were able to mention at least one protected area in the Eastern Ore Mountains. The by far most frequently mentioned protected areas were the nature reserves Geisingberg (32 mentions) and Georgenfeld raised bog (31), which are among the most important and typical protected areas in the region. Only $14 \%$ of TSP knew the term Natura 2000. They associated it with "conservation of flora and fauna", the "maintenance of the natural heritage and biodiversity in Europe", or "a network of protected areas"; however, two of them also associated it with restrictions, strict regulations and negative effects on the tourism sector.

The visitors stated that the provision of habitats for animal and plant species would be very important and should be secured on a permanent basis. They also placed high value on the landscape beauty and the recreational values. This is in accord with their reasons for travelling to the Ore Mountains. Compared with other ecosystem services, the production of food and other commodities was regarded as less important (Fig. 6).

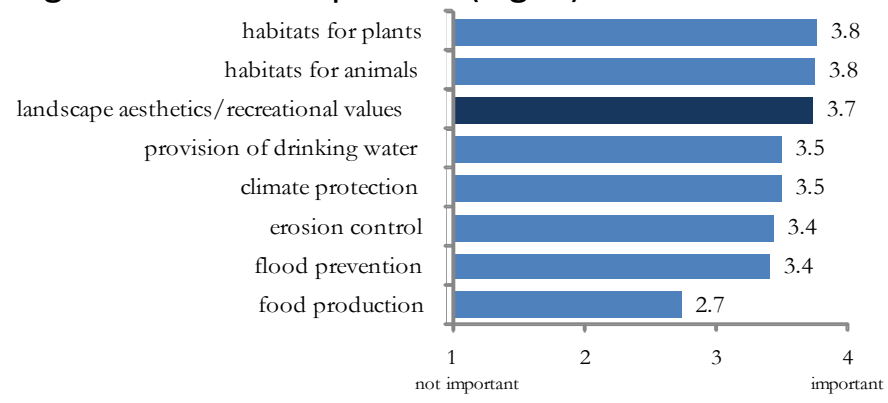

Fig. 6. The appreciation of various ecosystem services by visitors surveyed in the Eastern Ore Mountains (average values; large numbers values $=$ high ranks)

There were no significant differences between the two groups of visitors (except with respect to animal habitats, which were more frequently mentioned as important by visitors from outside the district weak significance $-10 \%$ level). Landscape aesthetic values, flood prevention (highest ranking: 53\%/32\%), and drinking water (60\%/44\%) were significantly more important for older than for younger persons.
People with lower education levels significantly valued food production (highest ranking: $28 \% / 14 \%$ ) and habitats for animals (88\%/72\%) higher than persons of higher education levels (cp. similar results for lower education levels in the Müritz National Park, for natural features that are often associated with animals; Lupp, et al. 2011).

\subsection{Attitudes towards ecosystem and landscape changes}

More than the half of the TSP feared that deforestation (70\%), wind turbines (60\%), the decline of biodiversity and the loss of mountain meadows (50\%) would reduce touristic attractiveness. Other unfavourable impacts mentioned included:

- The loss of panoramic views and the landscape character due to excessive afforestation of open areas

- Conflicts of interests between forestry and natural development, but also unfavourable recreational use of forests, e.g. snowmobiles and quad bikes

- General increase in motor traffic, also for leisure purposes

- Flood protection dams in beautiful valleys

- Air pollution from industry in the neighbourhood

- Too many protected areas that encumber the movement of tourists

- Elimination/limitation on skiing, hiking and mountain-biking routes

- Unmaintained, polluted rivers and river banks

The visitors stated that especially the loss of biodiversity and more technical infrastructure (wind turbines, industry, housing) would affect their choice of travel destination (Fig. 7).

With respect to wind turbines, visitors living in the district felt less deterred than visitors from outside the district (no impact $35 \% / 25 \%$, would choose 


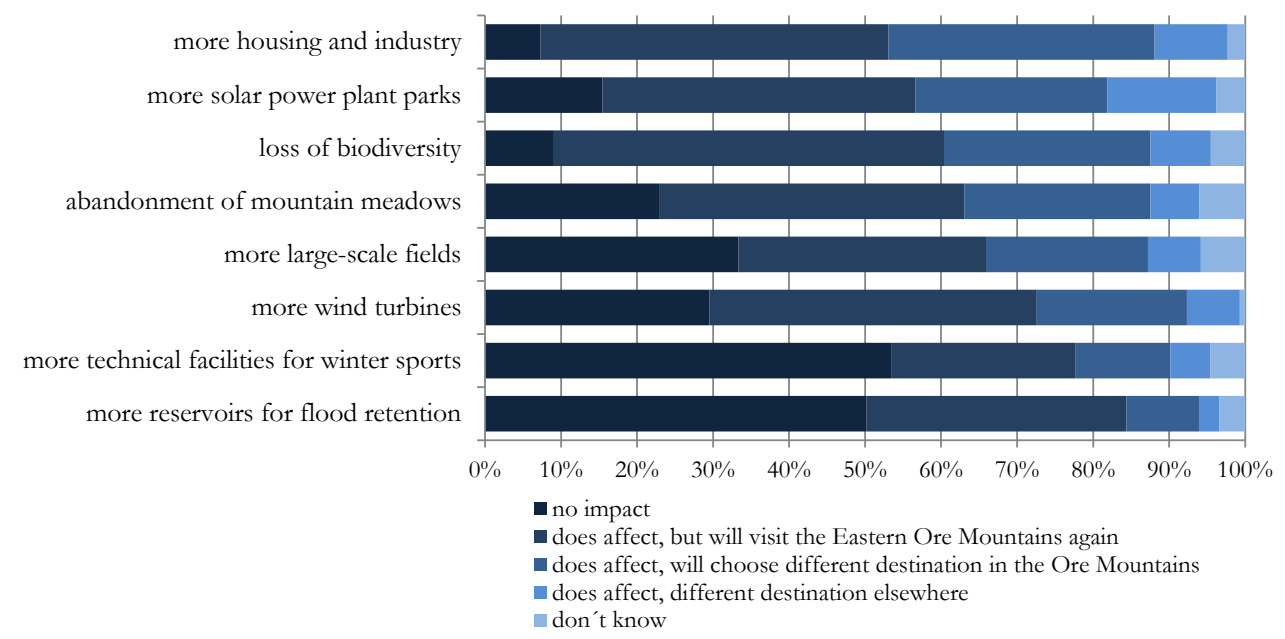

Figure 7: Impact of landscape changes on choice of destination for tourism/ recreation (external visitors' view, $\mathrm{n}=\mathbf{2 8 8}$ )

other destinations in the Ore Mountains 16\%/22\% or elsewhere $9 \% / 7 \%$ ), but there are no significant differences between older and younger persons. Younger people felt less deterred by solar power plants (weak significance $-10 \%$ level). A significantly higher acceptance of water reservoirs and winter sports facilities among older persons could be observed. Visitors from outside the district were

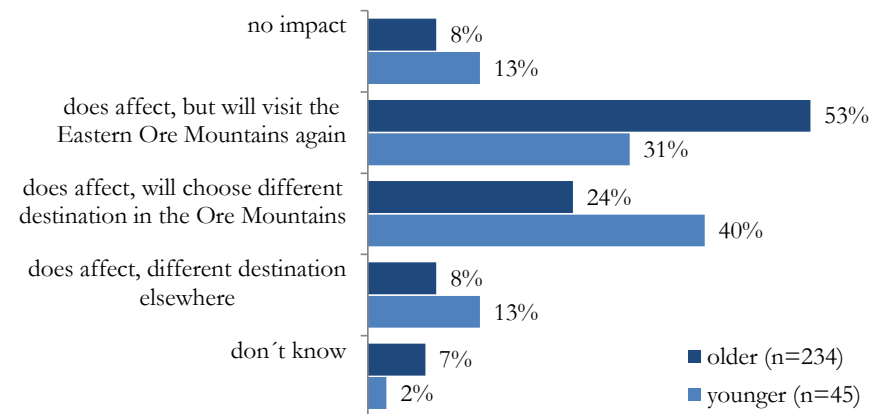

Figure 8: Assessment of biodiversity losses by people of different age groups and recreation patterns (younger people $=$ up to 40 years) more sensitive to biodiversity losses than residents of the district, and younger people saw it as a greater problem than older persons (Fig. 8).

\subsection{Willingness to pay (WTP) for nature conservation and landscape management}

More than two thirds of the responding TSP felt no responsibility for funding nature conservation and landscape management, stating that it is the task of the federal or state governments, or of landowners. Only $21 \%$ expressed the opinion that TSP and/or tourists should contribute. Tourists, they noted, had to pay the visitors' tax in any case, and the financial situation of the TSP precluded payment for nature conservation. Most TSP would prefer funding from general tax revenues (Table 3 ).

Of the visitors, $86 \%$ argued that the state or federal government should be responsible for nature conservation and landscape management (Fig. 9).

Table 3: Reasons of tourism service providers (TSP) for refusing payment for nature conservation

\section{Reasons}

Additional funding should come from donations

Additional funding should come from taxes

Tourism does not benefit from nature conservation

Demands of nature conservation for more funding are not justified

Other reasons

No response

$\begin{array}{ll}\text { Complaints } & \text { Share } \\ 3 & 6 \% \\ 32 & 63 \% \\ 3 & 6 \% \\ 6 & 12 \% \\ & \\ 14 & 27 \% \\ 6 & 12 \%\end{array}$


Here, too, most considered general tax revenues as the preferred instrument (Fig. 10).

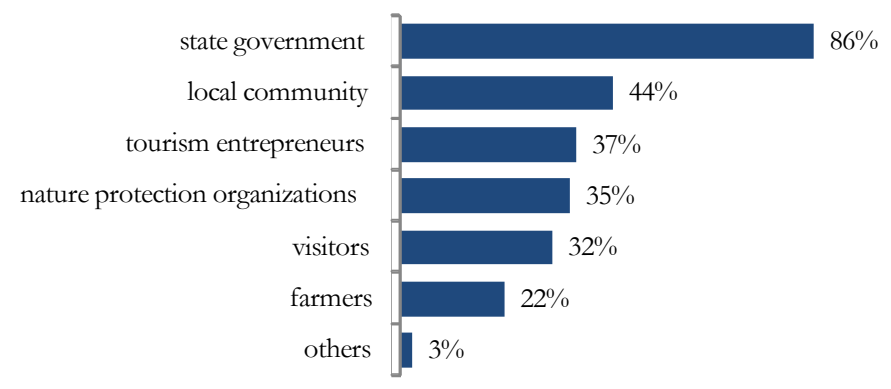

Figure 9: Responsibility for funding nature conservation in the view of visitors surveyed in the Eastern Ore Mountains ( $n=308)$

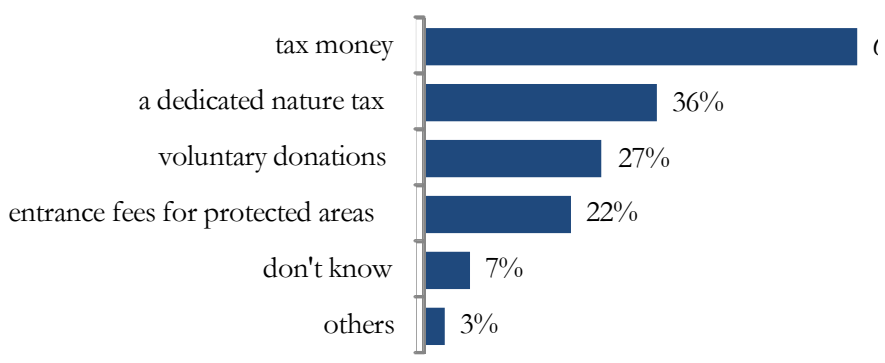

Figure 10: Types of payments for nature conservation accepted by visitors $(n=308)$

Younger people, more than older ones, saw a dedicated nature tax as an option. $68 \%$ of all visitors called for more and extra funding via such a tax, donations or entrance fees (Fig. 11).

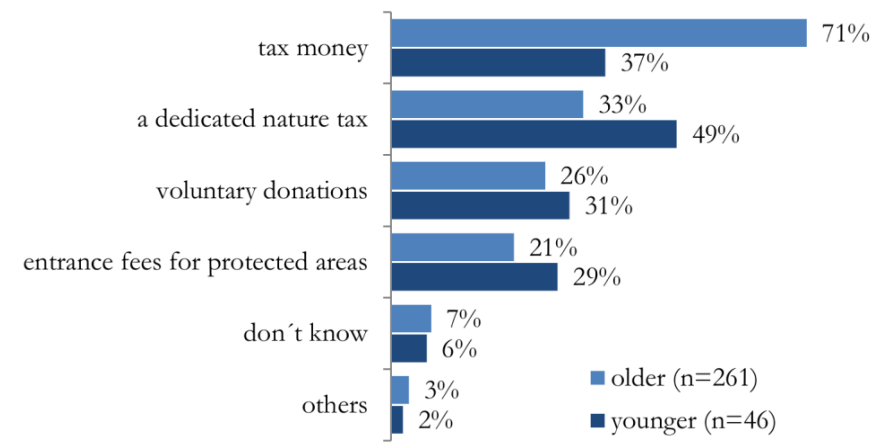

Figure 11: Differences between older and younger visitors in terms of accepted payment types for nature conservation (younger people $=$ up to 40 years)

Of those visitors not willing to pay, more than two thirds (71\%) argued that nature conservation should be funded from general taxes, and $22 \%$ believed that they could not afford more money. The last group can be considered real payment deniers, as they assign other goods a higher value than they do to nature. For the first group, this is not certain.

In order to estimate the amount of a possible financial contribution of the tourism sector or to quantify the WTP, the TSP were asked to measure the amount of taxes per guests and night (in the form of an open question); nine TSP replied, and the average of their estimates, which ranged between $€ 0.25$ - €3.00, was €1.36.

Less than half of the respondents $(42 \%$ of TSP surveyed) endorsed an increase in the visitors' tax to the amount of a nature tax in the Ore Mountains; $37 \%$ wanted no increase in the visitors' tax. Attitudes on this issue were quite divided. The proponents of the nature tax called for amounts ranging between $€ 0.20$ and $€ 3.00$, with an average of $€ 0.75$ per person per night $(n=14)$. Two thirds of those TSP who would be willing to bear some of the management costs believed that this money should best be paid to the local or regional landscape management associations, while $50 \%$ considered the municipalities and farmers to be suitable recipients; environmental organizations were also mentioned.

The survey of visitors resulted in a WTP amount of between $€ 1.06$ and $€ 2.73$ per visitor per day, or between $€ 5.03$ and $€ 18.91$ per resident of the district per year (see Table 4). The lower values represent the arithmetic mean of all respondents, including those not willing to pay (entered into the calculation with a WTP of $€ 0$ ). The higher values exclude the payment deniers (84). The five respondents who expressed WTP, but did not call for any particular amount, were treated as having an average WTP equal to that of those who participated (methodological notes: Meyerhoff et al. 2010).

The question as to the acceptance of the current entrance fee ( $€ 1.80)$ to the Georgenfeld raised bog nature reserve resulted in even higher WTP amounts: the 261 external visitors surveyed considered it appropriate or even too low. Only 5\% did not accept the existing fee. The acceptance quota of the entrance fee to the bog was dependent on the site where the survey was carried out. It was higher 
among the visitors to the bog than among those to the mountain meadows.

Both groups of visitors felt a responsibility to better support nature conservation. Respondents living in the district stated a significantly higher willingness to pay (significant on the $5 \%$ level) $€ 7.59$ per year, on average - than respondents from outside the district expected from them ( $€ 3.51$, on average). The reverse was also true: residents of the district expected "guests" to pay an average of €0.71 per day, while the latter actually stated a willingness to pay $€ 1.20$, on average ( $5 \%$ level). The overall WTP of younger respondents was higher than that of older ones (highly significant $-1 \%$ level; but no significance concerning the Georgenfeld raised bog entrance fee). With respect to education levels, no significant differences could be found. We could establish no clear correlation between income levels and WTP of visitors (statistically checked by regression analysis and Spearman rank correlation coefficient).

Table 4: WTP of visitors for nature conservation and landscape management (in the Eastern Ore Mountains generally and for the Georgenfeld raised bog)

\begin{tabular}{|c|c|c|c|}
\hline & $\begin{array}{l}\text { Suggested } \\
\text { amount per day } \\
\text { for visitors from } \\
\text { outside the } \\
\text { district }\end{array}$ & $\begin{array}{l}\text { Suggested } \\
\text { amount per } \\
\text { resident (of the } \\
\text { district) and } \\
\text { year }^{1}\end{array}$ & $\begin{array}{c}\text { Proposed entrance } \\
\text { fee for the } \\
\text { Georgenfeld raised } \\
\text { bog } \\
\text { (current fee: } \\
€ 1.80)^{2}\end{array}$ \\
\hline \multicolumn{4}{|l|}{ All interviewees $(n=308)$} \\
\hline Mean & $€ 1.06$ & $€ 5.03$ & $€ 1.95$ \\
\hline Quote "Willing to pay" & $€ 2.73$ & $€ 18.91$ & $€ 3.30$ \\
\hline \multicolumn{4}{|c|}{ Residents of the district ( $n=92$ ) } \\
\hline Mean & $€ 0.71$ & $€ 7.59$ & $€ 2.03$ \\
\hline Quote "Willing to pay" & $€ 1.98$ & $€ 22.52$ & $€ 2.42$ \\
\hline \multicolumn{4}{|c|}{ Visitors from outside the district $(n=216)$} \\
\hline Mean & $€ 1.20$ & $€ 3.51$ & $€ 1.91$ \\
\hline Quote "Willing to pay" & $€ 2.32$ & $€ 16.48$ & $€ 2.24$ \\
\hline \multicolumn{4}{|l|}{ Older $(>40$ years, $n=261)$} \\
\hline Mean & $€ 0.89$ & $€ 3.76$ & $€ 1.98$ \\
\hline Quote "Willing to pay" & $€ 2.11$ & $€ 17.54$ & $€ 2.32$ \\
\hline \multicolumn{4}{|c|}{ Younger $(\leq 40$ years, $n=47)$} \\
\hline Mean & $€ 1.88$ & $€ 9.27$ & $€ 1.66$ \\
\hline Quote "Willing to pay" & $€ 2.71$ & $€ 22.70$ & $€ 2.14$ \\
\hline \multicolumn{4}{|c|}{ Lower Education level ( $n=88$ ) } \\
\hline Mean & $€ 0.95$ & $€ 4.43$ & $€ 1.84$ \\
\hline Quote "Willing to pay" & $€ 2.15$ & $€ 14.98$ & $€ 2.22$ \\
\hline \multicolumn{4}{|c|}{ Higher Education level ( $n=204)$} \\
\hline Mean & $€ 1.15$ & $€ 5.18$ & $€ 2.06$ \\
\hline Quote "Willing to pay" & $€ 2.32$ & $€ 21.13$ & $€ 2.31$ \\
\hline
\end{tabular}

\footnotetext{
${ }^{1}$ Five interviewees gave no amount, we assumed the average value for them.

${ }^{2}$ Those willing to pay but giving no amount $\rightarrow$ assumption of $€ 1.80$
} 


\section{Discussion}

\subsection{Appreciation of nature and landscape}

The results of the surveys showed that the attractiveness of the Eastern Ore Mountain landscape is very important for the tourism sector. It is seen as the main reason to spend holidays or leisure time there. This agrees with the results of similar studies, by Grunewald et al. (2012) in the Western Ore Mountains and Lupp \& Konold (2008) in the Müritz Region (northern Germany), where most tourists cited beauty, harmony and naturalness of the landscape as key travel motivations. Our interviewees mentioned experiencing nature as a key reason for visiting the Ore Mountains more often than the TSP assumed for their guests (see also Fig. 5 - the higher appreciation of landscape elements by visitors than by TSP). The reason might be that the survey was conducted on-site near the nature reserves, where mostly nature-loving visitors can be found, while the TSP had a wider spectrum of tourists in mind. This is in line with the impression that the visitors regretted a possible loss of biodiversity more than the TSP did.

Most TSP in the Eastern Ore Mountains argued that the loss of landscape elements, particularly mountain meadows, would have negative consequences for tourism, and that conservation and management measures are very important, too, from a touristic point of view. This high regard for mountain meadows could be also due to the fact that great efforts are presently being made to protect and restore mountain meadows in the region through the large-scale conservation project "Mountain Meadows in the Eastern Ore Mountains" (Hachmöller et al. 2001).

The fact that no more than $71 \%$ of TSP could name a protected area, and that the term "Natura 2000" was familiar to a mere $14 \%$ of them revealed knowledge deficits in terms of nature conservation highlights. Of the only 20 surveyed TSP in the Western Ore Mountains, 18 (90\%) could name protected areas in that region, and 11 (55\%) viewed them positively (Grunewald et al. 2012). With respect to knowledge of the term biodiversity, only $42 \%$ of respondents in a nationwide survey (BMU 2012) were familiar with the term. These facts indicate despite a general high appreciation of "nature", there is a need for more publicity work aimed at broadening the scope of nature conservation awareness especially considering the protected areas and their needs for respective management to maintain their character, which are also important key cornerstones of the tourism in this area. This is very important, in particular for TSP, as they play a multiplier role for the many tourists visiting the region. Appropriate education and awareness-raising initiatives, especially by the tourism associations, should be enhanced.

Impacts of interventions in nature (e.g. reforestation, extension of agricultural activities or construction of wind power plants) on landscape perceptions may vary between different social groups (Hunziker et al. 2008). Moreover, studies on the impact of particular landscape changes on the tourism attractiveness of destinations come to different conclusions. In regard to the installation of wind turbines, some authors point to possible shifts in the destination choice of tourists (Bundesverband deutsche Mittelgebirge/ Centouris 2012; Grunewald et al. 2012), whereas others do not believe in major negative impacts on landscape perceptions and experiences (Frantal \& Kunc 2011). Not surprisingly, the sensitivity to the placement of turbines rises in accordance with higher aesthetic quality levels of landscapes (Molnarová et al. 2012).

The surveys in the Western Ore Mountains (Grunewald et al. 2012) confirmed the findings that deforestation and wind turbines were seen as impairing the scenery significantly; there, $82 \%$ (deforestation) and 73\% (wind turbines), respectively, of summer tourists responded accordingly, while the figures in the present Eastern Ore Mountains survey were $82 \%$ and $74 \%$, respectively (see Fig. 4). Highly visible landscape changes were mentioned more frequently than qualitative impacts on such sensitive ecosystems as raised bogs, or the decline of biodiversity in general. These clear statements of aesthetic preferences should be seen as a warning signal from the tourism sector to limit the expansion of wind power use, and to keep sensible areas, 
particularly the ridge zone free of wind turbines.

The spoiling of the landscape would, according to the Western Ore Mountains study (Grunewald et al. 2012), also change the travel behaviour of the tourists surveyed there: $28 \%$ of winter tourists and $23 \%$ of summer tourists would definitely change their travel destinations, and $34 \% / 28 \%$ would probably do so. Only $24 \%$ of winter tourists and $39 \%$ of summer tourists would remain faithful to the region, while $13 \% / 9 \%$ are still undecided. Depending on the particular impact, between $10 \%$ and $36 \%$ of visitors in the Eastern Ore Mountains would change the destination of travel and recreation.

Without knowing the concept of ecosystem services explicitly, Germans in general appreciate nature due to its manifold services for humans (BMU 2012): The majority demands that nature be used in such a manner that it remains available in full for future generations (93\%), that the diversity of plants, animals and their habitats is secured (93\%), and that the beauty and peculiarity of the landscape is maintained (92\%). More than half of all Germans can imagine becoming active for nature conservation, or declared that they are already active (18\%). This is a remarkably considerable segment of the population. Persons over the age of 65 years and well-educated people display an above average level of activity (BMU 2012). The great majority see the conservation of biological diversity as an important task of the society. About one half of the surveyed people feel personally responsible for ensuring this goal. Among the responding visitors in the Eastern Ore Mountains survey, $68 \%$ would be ready to contribute in monetary terms! This is in line with the nation-wide survey (BMU 2012): 65\%!

We could find some differences in the answers depending on origin (residents of the district/ visitors from outside), age and education level. Petrosillo et al. (2007) showed a high dependence of tourists' perception of recreational environment and management on gender, education level, and place of residence, and stressed the importance of better identification of visitors' profile, to achieve better management of tourism development.

\subsection{Funding of nature conservation and landscape management}

An attractive landscape is a public good; nobody can be excluded. However, conservation and management costs must be covered. Tourism providers benefit from the increased attractiveness of a landscape without bearing any of the associated costs. This is a typical "free rider problem". The nature tax may be a payment model to solve this problem at least partially. All guests are obliged to contribute to an attractive landscape (Huhtala \& Pouta 2008). However, not all users of the improved state of nature and landscape are reached by this model, e.g. day-trippers, local residents and their guests (Degenhardt et al. 1998). As most TSP see not the tourism sector, but rather the general public as being responsible for nature conservation and landscape management, they are opposed to the nature tax. Some of them argued that after establishing a nature tax, the state might shrink its responsibility in times of tight budgets. The financial means available for nature conservation would depend on the tourism development of the region. But even in regions less important for tourism, funds are needed. Moreover, nature conservation should not depend on tourism, since nature is not protected for touristic reasons alone. Such funding models are also perceived as an inadequate tool because of the well-known and very common right to visit nature free of charge. Also, many other WTP studies have ascertained that financing through general tax revenues is the most popular model (Degenhardt et al. 1998).

The height of WTP (or nature tax) determined in the Eastern Ore Mountains ( $€ 0.75$ tourists' nature tax or $€ 1.36$ as payment of TSP per day and tourist, or between $€ 1.06$ and $€ 2.73$ as average visitor's WTP per day) is similar to the Western Ore Mountains (€1-2) (Grunewald et al. 2012). This is in line with the results from Ireland (Yadav \& O'Neill 2013), were the tourists believed that the TSP should pay almost twice as much as their contribution and just $22 \%$ of the TSP stated that tourists should make any contribution (Eastern Ore Mountains: 21\%).

Numerous critics, however, have pointed out that the method is fraught with technical and conceptual problems. Thus, the survey design 
and the description and framing of what is to be valued is critical to the reliability of the method, and the information a survey provides as well as the order in which questions are asked substantially influences WTP (Riera et al. 2012). The results may be influenced by the specific location of the survey, the composition and characteristics of the reference group, particularly their level of income and education, prior knowledge, preconceived opinions, level of understanding, and psychological aspects. Also various socio-economic variables, like the GDP or the income per capita, have an influence on WTP estimates (Barrio \& Loureiro 2010).

Jones-Walters \& Mulder (2009) argue that the fundamental objections with respect to WTP valuations should not be dismissed, not only due to the discrepancy between the stated preferences and the actual behaviour of respondents, but also with regard to their knowledge and rationality (Jessel et al. 2009). WTP is not based on actual market behaviour (Chee 2004). An overestimation, i.e. the amount by which the actual WTP exceeds the theoretical WTP obtained in surveys, by a factor of 2.5 is possible. On the other hand, stated preferences and actual payments are often not adequate to the real benefits and values of the natural environment. WTP analyses fail to capture all benefits and beneficiaries. Nature conservation provides not only recreation benefits, but also existence values, which benefit all people, not only the tourists and residents seeking recreation, or the TSP of the tourist resorts (Schweppe-Kraft 2009).

Much of the attention devoted to ecosystem services valuations incl. WTP approaches stems from the hope that it will result in better decisions about the environment. This requires that valuation is actually used for decisions, and that it has a significant impact on these decisions (Laurans \& Mermet 2014). Such valuations have the potential to inform policy decisions by highlighting the benefits of sustainable ecosystem management. Unfortunately, as already stated above, the techniques used for valuation suffer from serious limitations. Ecosystem management problems are often complex, multi-faceted, socially contentious and fraught with uncertainty. For policy makers ecosystem services valuation is not the most important factor, but it provides a set of tools with which to make better and more informed decisions. As Chee (2004) emphasises, the welfare economic approach to decision-making is too narrowly focussed and needs to be supplemented by more comprehensive approaches like substantive stakeholder participation with opportunities for social learning, value formation, problem exploration, risk assessment, analysis of uncertainty, broad-based debate and reconciliation of interests.

One could argue that from the fact that in our study the interviews were carried out at nature reserves methodological weaknesses may result, because the survey over-represents nature-oriented people, but not the opinions and behaviour of the "average" total population visiting or living in the region. But: As a nation-wide survey on nature consciousness (BMU 2012) shows, there is a huge demand of high environmental standards and a great relevance for environmental protection in almost all groups of society. About three quarters of the total population in Germany expressed the view that nature is very important for them. Hence, the methodical bias of our survey near nature reserves might be relativised.

The funds spent for landscape management are an expression of the economic value of landscape and nature. There is a broad political and social consensus for protecting environment, biodiversity and valuable landscapes (revealed public preferences). National and international laws underpin such goals and regulations as the European network Natura 2000. The measures for nature conservation and landscape management entail costs, which can be seen as a measure of the public's WTP to achieve defined goals (UBA 2007). In this respect it would be interesting to determine whether this WTP really covers the level of funding needed or actually spent for landscape management.

\subsection{Willingness to pay and landscape management costs}

But what about the real costs of landscape management? In Saxony $420 € /$ ha are needed annually for the management of the protected biotope type "mountain meadow" (Grunewald \& Syrbe 2012; Grunewald et al. 2014). In 2010, $€ 163,380$ were used for the regular management 
of 389 ha of mountain meadows in the district of Sächsische Schweiz-Osterzgebirge ( $€ 420 \times 389$ ha). For all valuable biotope types of the district which need management measures, a total of $€ 1,119,678$ were calculated (Grunewald \& Syrbe 2012).

We have noticed that under different assumptions, the WTP analyses among TSP resulted in monetary amounts varying between $€ 0.75$ and $€ 1.36$ in the study area (see sect. 3.4). If the TSP of Altenberg and Hermsdorf had collected $€ 1.36$ per guest per night in $2011, € 565,000$ would have been available for nature conservation and landscape management $(415,844$ overnight stays without campsites - http://www. statistik.sachsen.de/appsl1/Gemeindetabelle). Based on the proposed nature tax of $€ 0.75, € 312.000$ would have been available. The costs of the largescale conservation project "Mountain Meadows of the Eastern Ore Mountains" (see sect. 4.1), which is located within the municipal borders of Altenberg, were $€ 600,000$ annually from 2000 to 2008, and are $€ 567,000$ annually from 2010 to 2015 . These costs include biotope management, acquisition of land, and such transfer costs as administration and public relations. Thus, the majority of the annual costs for nature conservation and landscape management could be covered by public funds, primarily tax revenues, if the results of the WTP approach were to be used as orientation for the demand (stated preference) of society and a measure of justified redistributions of tax-payers' money for nature conservation and landscape management.

Grunewald et al. (2012) determined a WTP of $€ 170,000$ per year for nature conservation and landscape management in their study area in the Western Ore Mountains ( $€ 4.50$ per tourist arrival). By contrast, only one tenth of this amount was actually spent in 2009! It is not easy to calculate a total amount from the WTP data obtained from the survey among tourists. Total tourist frequentation of all relevant biotopes or nature reserves per year in the area is not known. For the Georgenfeld raised bog the number of tickets sold is a measure for this particular site: In 2012, a total of 13,949 persons and 462 families with four and more members visited the bog. The sum of the fees paid was $€ 24,040$ (there were different entrance fees for adults, adults with visitor's cards, children, children with visitor's cards, and school classes). The fees together with the sale of drinks, ice-cream and postcards covered the costs for the staff of the nature reserve.

The Schellerhau botanical garden, which is specialized in the mountain flora, was visited by 8,500 paying visitors in 2012 (average entrance fee: $€ 1.72$ ), and provided 3,123 free entries. If we assume theoretically the same fee for the last group, the total sum would have been $€ 20,124$. These two items represent only a very small part of all nature sights in the study area. However, for legal and practical reasons, it is impossible and not reasonable to charge entrance fees for all of them.

It is interesting that the actual WTP for public environmental goods is - as a rule - much higher than the costs of the provision and maintenance of these goods (Schweppe-Kraft \& Grunewald 2014). Hampicke et al. (1991) found that the number the Germans prepared to pay for biodiversity in their country would be more than twice the estimated costs of measures needed to preserve all ecosystems essential for the conservation of species in Germany. Recent studies have shown an even higher WTP (Schweppe-Kraft 2009; Meyerhoff et al. 2010). Each hectare of protected areas (nature reserves) would benefit to the tune of $€ 1000$ per year. The costbenefit-ratio is positive, which means that sustaining biodiversity is economical, even if only existence and aesthetic motives are considered. For Natura 2000 in Europe, about $€ 63 / \mathrm{ha} / \mathrm{yr}$ are necessary; however, these costs are by far exceeded by the benefits, e.g. from carbon sequestration and tourism, even if not all ecosystem services are included in the calculation (Kettunen et al. 2009).

The question is: Why are adequate nature conservation programmes not implemented in practice? The reasons may be the general mistrust of contingent valuations and the lack of hard facts in the area of biodiversity (Schweppe-Kraft 2009).

The issue of the tourism sector's contribution to nature conservation and landscape management should be kept under review. In further investigations larger samples might allow for better differentiation among respondents, and for the sampling of larger groups for statistical analyses of lifestyles. It would 
also be interesting to reveal any differences in appreciation of nature and the landscape, and in WTP, between the German and Czech sides of the Ore Mountains, respectively.

\section{Conclusions}

T raditional landscape planning concepts are oriented mainly towards the properties and potentials of ecosystems and the landscape, i.e. the supply side. The concept of ecosystem services is focussed more on the demand side, i.e. on the values and benefits as well as the providers and beneficiaries of services. At the interface of nature conservation and tourism, stated preference analyses are useful to reveal the needs, wishes and motivations of stakeholders. The survey carried out in the Eastern Ore Mountains has revealed the clear expression by tourism service providers (TSP) and tourists that they regard the attractive landscape as the main reason to visit this region, and that leisure activities in nature have by far the highest priority for visitors.

Attractive sceneries are considered being very important, especially such landscape elements as mountain meadows and mountain mixed forests. Deforestation, wind turbines, biodiversity loss and decline of mountain meadows reduce the attractiveness for outdoor recreation. Thus, nature conservation, landscape management and sustainable use are seen as very important, from the point of view of tourism as well. The lack of knowledge of nature conservation issues (protected areas, Natura 2000) draws attention to the need for information and education, particularly in view of the fact that TSP are important multipliers in the region.

Although the majority of TSP and visitors see the state and the public as responsible for funding nature conservation and landscape management, and tax revenue as the most appropriate financial source, a remarkably significant segment is prepared to contribute to covering such expenses. The amounts ascertained by the WTP analyses would be sufficient to cover most of the costs of nature conservation and landscape management in the study area. Since especially rural and peripheral regions benefit from nature-based tourism (Bell et al. 2007), politicians could see this as a call to implement these measures, which also support and secure tourism and jobs in this rural region.

Economic valuation, including contingent valuation, is just one aspect within the ecosystem service concept, and not necessarily the adequate and optimum indicator or instrument for resource management (Seppelt et al. 2012). Especially for goods without real markets (e.g. biodiversity, beauty of landscape), it should be applied only as an accompanying factor, not as the only basis to justify decisions or to choose options for action, particularly when weighing longterm aspects against short-term benefits (e.g., the construction of wind turbines in sensitive areas, or the underfunding of biotope management). Despite all problems and limitations, stated preference analyses belong to the most widely accepted and used methods for expressing the demand side in ecosystem services valuations (Riera et al. 2012).

They reveal not only the amount that people would be prepared to pay, but also the conditions or developments in the environment which they desire, or want to avoid. Valuations and surveys as performed in this study can help to set priorities for landscape management and for optimizing open space planning, in particular with regard for the preferences of people for certain landscape elements.

On the basis of such assessments, it is then possible to determine the actions and the limits required to avoid deteriorations (Grunewald et al. 2012). In order to establish successful environmental policies for the maintenance of biodiversity, ecosystem services and landscape qualities, and for the sustainability of an area, the users must be involved, and their opinions and preferences as well as their attitudes towards its conservation must be properly understood (Martín-López et al. 2007; Radford \& James 2013). It is also useful to develop suitable funding models to balance the distribution of benefits and costs of nature conservation and landscape management, e.g. by involving beneficiaries (Macke \& Schweppe- 
Kraft 2011). Nevertheless, there is an urgent need for further studies and enhanced methodological approaches to bridge from the assessment of nature and landscape to practical decision-making, particularly in the area of landscape management.

\section{Acknowledgements}

The study was conducted in the framework of the projects "Grünes Netzwerk Erzgebirge" (Ore Mountains Green Network) and "Mehrwert Natur Ost-Erzgebirge" (Eastern Ore Mountains Ecosystem Services), and supported by the European Union, the State of Saxony and the Czech Republic. The students of the Dresden University of Technology, Chair of Tourism Economics and Management, M. Arjes, D.C. Bestfleisch, N. Jacob, P. Kleber, and M. Milde carried out a major part of the on-site surveys. Ms. A. Zimmermann (Gemeinnützige $\mathrm{GmbH}$ Naturbewahrung Osterzgebirge) provided visitor statistics of the Georgenfeld raised bog and the Schellerhau botanical garden. We thank Phil Hill, Berlin, for polishing the language.

\section{References}

Arnegger, J.; Woltering, M. \& H. Job 2010. Toward a product-based typology for nature-based tourism: a conceptual framework. Journal of Sustainable Tourism 18, 915-928.

Atteslander, P. 2010. Methoden der empirischen Sozialforschung. (Methods of empirical sociological research). Erich Schmidt: Berlin New York. 10th ed.

Barrio, M. \& M.L. Loureiro 2010. A meta-analysis of contingent valuation forest studies. Ecological Economics 69, 1023-1030.
Bastian, O. 2013. The role of biodiversity in supporting ecosystem services in Natura 2000 sites. Ecological Indicators 24, 13-22.

Bastian O.; Haase D. \& K. Grunewald 2012. Ecosystem properties, potentials and services - The EPPS conceptual framework and an urban application example. Ecological Indicators 21, 7-16.

Bastian, O.; Neruda, M.; Filipová, L.; Machová, I. \& M. Leibenath 2010. Natura 2000 sites as an asset for rural development: the German-Czech Ore Mountains Green Network Project. J. Landscape Ecol. 3, 41-58.

Bell, S.; Tyrväinen, L.; Sievänen, T.; Pröbstl, U. \& M. Simpson 2007. Outdoor Recreation and Nature Tourism: A European Perspective. Living Reviews in Landscape Research 1(2). http://www. livingreviews.org/IrIr-2007-2. (Date: 29.10.2014).

Beza, B.B. 2010. The aesthetic value of a mountain landscape: A study of the Mt. Everest Trek. Landscape and Urban Planning 97, 306-317.

Blamey, R.K. 2001. Principles in ecoturism. In: Weaver, D.B. (ed.). The encyclopedia of ecotourism. CABI Publishing: Oxon - New York; pp. 5-22.

BMWi 2013. Tourismusperspektiven in ländlichen Räumen: Handlungsempfehlungen zur Förderung des Tourismus in ländlichen Räumen. German Federal Ministry of Economics and Technology (Tourism perspectives in rural areas: recommendations for improving tourism in rural areas); Berlin.

BMU 2012. Naturbewusstsein 2011. Bevölkerungsumfrage zu Natur und biologischer Vielfalt. (Natural awareness 2011. Population survey about nature and biological diversity). German Federal Ministry for the Environment, Nature Conservation, Building and Nuclear Safety, Berlin \& ECOLOG-Institute; Hannover. 
BMU \& BfN 2014. Naturbewusstsein 2013. Bevölkerungsumfrage zu Natur und biologischer Vielfalt. (Natural awareness 2013. Population survey about nature and biological diversity). German Federal Ministry for the Environment, Nature Conservation, Building and Nuclear Safety, Berlin \& German Federal Agency for Nature Conservation, Bonn.

Bundesverband deutsche Mittelgebirge/Centouris 2012. Akzeptanz von Windenergieanlagen in deutschen Mittelgebirgen (Acceptance of wind turbines in German mow mountain ranges). Passau.

Butler, C.D. \& W. Oluoch-Kosura 2006. Linking future ecosystem services and future human wellbeing. Ecology and Society 111:30. http://www. ecologyandsociety.org/vol11/iss1/art30 (Date: 4.10.2014).

Casado-Arzuaga, I.; Madariaga, I. \& M. Onaindia 2013. Perception, demand, and user contribution to ecosystem services in the Bilbao Metropolitan Greenbelt. J. Environm. Management 129, 33-43.

Chee, Y.E. 2004. An ecological perspective on the valuation of ecosystem services. Biological Conservation 120, 549-565.

Coghlan, A. \& R. Buckley 2013. Nature-based tourism. In: Holden, A. \& D.A. Fennell (eds.): The Routledge Handbook of Tourism and the Environment. Routledge; London et al.; pp. 334-344.

Cook, C., Heath, F., Thompson, R.I. 2000. A metaanalysis of response rates in web- or internetbased surveys. Educational and Psychological Measurement 60, 821-836.

Curtin, S. 2013. The intrinsic motivations and psychological benefits of eco- and wildlife tourism experiences. In: Ballantyne, R. \& J. Packer (eds.): International Handbook on Ecotourism. Edward Elgar; Cheltenham - Northampton; pp. 203-216.
Degenhardt, S.; Hampicke, U.; Holm-Müller, K.; Jaedicke,W.\&C.Pfeiffer1998.Zahlungsbereitschaft für Naturschutzprogramme (Willingness to pay for nature conservation programmes). Angewandte Landschaftsökologie 25. Bonn; Federal Agency for Nature Conservation.

DESTATIS 2014. Einkommen der privaten Haushalte in den kreisfreien Städten und Landkreisen der Bundesrepublik Deutschland 2000 bis 2012, Reihe 2, Band 3. (Income of households in the districts of the Federal Republic of Germany from 2000 to 2012) https://www. destatis.de/DE/Publikationen/Thematisch/ VolkswirtschaftlicheGesamtrechnung/ VGRderLaender/VGR_KreisergebnisseBand3. html (Date: 3.12.2014)

Elsasser, P.; Meyerhoff, J.; Montagné, C. \& A. Stenger 2009. A bibliography and database on forest valuation studies from Austria, France, Germany and Switzerland -A possible base for a concerted European approach. Journal of Forest Economy 15, 93-107.

Farber, S.; Costanza, R.; Childers, D.L.; Erickson, J.; Gross, K.; Grove, M.; Hopkinson, C.S.; Kahn, J.; Pincetl, S.; Troy, A.; Warren, P. \& M. Wilson 2006. Linking ecology and economics for ecosystem management. Bioscience 56, 117-129.

Frantál, B. \& J. Kunc 2011. Wind turbines in tourism landscapes: Czech Experience. Annals of Tourism Research 38, 499-519.

Fredman, P. \& K. Lindberg 2008. Special Focus: Mountain tourism - Introduction. Tourism Economics 14, 245-247.

FUR 2013. Reiseanalyse 2013 (Travel analysis 2013). Kiel; Forschungsgemeinschaft Urlaub und Reisen.

García-Nieto, A.P.; García-Llorente, M.; IniestaArandia, I. \& B. Martín-López. 2013. Mapping forest ecosystem services: From providing units to beneficiaries. Ecosystem Services 4, 126-138. 
Grunewald, K. \& R.-U. Syrbe 2012. Landschaftspflegestrategie Sachsen 2020 - Bilanz und Aufgabenschwerpunkte. (Landscape management strategy, Saxony 2020 - Accounting and key tasks). State Agency for the Environment, Agriculture and Geology of Saxony. Series, No. 20, Dresden.

Grunewald, K.; Syrbe, R.-U. \& O. Bastian 2014. Landscape management accounting as a tool for indicating the need of action for ecosystem maintenance and restoration - Exemplified for Saxony. Ecological Indicators 37, 241-251.

Grunewald, K.; Syrbe, R.-U. \& C. Renner 2012. Analyse der ästhetischen und monetären Wertschätzung der Landschaft am Erzgebirgskamm durch Touristen (Aesthetic and monetary appreciation of Ore Mountains scenery by tourists). GEOÖKO 33, 34-65.

Hachmöller, B.; Menzer, H.; Kafurke, B. \& B. König 2001. Naturschutzgroßprojekt Bergwiesen im Osterzgebirge. (Large nature conservation project "Mountain Meadows in the Eastern Ore Mountains"). Natur und Landschaft 76, 442-453.

Hampicke, U.; Horlitz, T.; Kiemstedt, H.; Tampe, K.; Timp, D. \& M. Walters 1991. Kosten und Wertschätzung des Arten- und Biotopschutzes. (Costs and appreciation of the conservation of species and biotopes), Reports 3/91. German Federal Environment Agency, Berlin.

Heuchele, L.; Renner, C.; Syrbe, R.-U.; Lupp, G. \& W. Konold 2014. Nachhaltige Entwicklung von Tourismusregionen im Kontext von Klimawandel und biologischer Vielfalt. (Sustainable development of tourism regions in the context of climate change and biodiversity). Culterra 64, University Freiburg.

Honey-Rosés, L. \& L.H. Pendleton 2013. A demand driven research agenda for ecosystem services. Ecosystem Services 5, 160-162.
Huhtala, A. \& E. Pouta 2008. User fees, equity and the benefits of public outdoor recreation services. Journal of Forest Economics 14, 117-132.

Hunziker, M.; Felber, P.; Gehring, K.; Buchecker, M.; Bauer, N. \& F. Kienast 2008. Evaluation of landscape change by different social groups. Mountain Research and Development 28, 140147.

Jessel, B.; Tschimpke, O. \& M. Walser 2009. Produktivkraft Natur. (Nature as a productive factor). Hoffmann und Campe: Hamburg.

Jones-Walters, L. \& I. Mulder 2009.Valuing nature: The economics of biodiversity. Journal of Nature Conservation 17, 245-247.

Kettunen, M.; Bassi, S.; Gantioler, S. \& P. ten Brink. 2009. Assessing socio-economic benefits of Natura 2000 - a toolkit for practitioners (September Edition). Output of the European Commission project Financing Natura 2000: Cost estimate and benefits of Natura 2000. Institute for European Environmental Policy (IEEP), Brussels.

Kösterke, A. \& D. von Laßberg. 2005. Urlaubsreisen und Umwelt: eine Untersuchung über die Ansprechbarkeit der Bundesbürger auf Naturund Umweltaspekte in Zusammenhang mit Urlaubsreisen. (Holiday trips and environment: an investigation into the responsiveness of German citizens to aspects of nature and environment related with holiday trips.) Ammerland; Studienkreis für Tourismus und Entwicklung.

Laarman, J.G. \& H.M.Gregersen 1996. Pricing policy in nature-based tourism. Tourism Management $17,247-254$.

Lamarque, P.; Tappeiner, U.; Turner, C.; Steinbacher, M.; Bardgett, R.D.; Szukics, U.; Schermer, M. \& S. Lavorel 2011. Stakeholder perceptions of grassland ecosystem services in relation to knowledge on soil fertility and biodiversity. Regional Environm. Change 11, 791-804. 
Laurans, Y. \& L. Mermet 2014. Ecosystem services economic valuation, decision-support system or advocacy? Ecosystem Services 7, 98-105.

Lee, C.-K. \& S.-Y. Han 2002. Estimating the use and preservation values of national parks' tourism resources using a contingent valuation method. Tourism Management 23, 531-540.

Lupp, G. \& W. Konold 2008. Landscape preferences and perception of both residents and tourists. A case study in Müritz National Park (Germany). In: Siegrist, D.; Clivaz, C.; Hunziker, M. \& S. Iten (eds.). Visitor Management in Nature-based Tourism - Strategies and Success Factors for Parks and Recreational Areas. HSR College Rapperswil, Switzerland; pp. 47-58.

Lupp, G.; Höchtl, F. \& W. Wende 2011. "Wilderness" - A designation for Central European landscapes? Land Use Policy 28, 594-603.

Lupp, G.; Syrbe, R.-U.; Heuchele, L.; Renner, C.; Konold, W. \& D. Siegrist 2014. Partizipative Szenarien als Erfolgsmodell für eine integrierte Entwicklung? Strategieentwicklung im Kontext von Tourismus, erneuerbarer Energie, Sicherung der biologischen Vielfalt und Klimaanpassung in Großschutzgebieten. (Participative Scenarios as Recipe for Success for Integrated Development? Strategies in the context of tourism, renewable energies, conservation of biodiversity, and climatic adaptation on large-scale conservation areas). Naturschutz und Landschaftsplanung. Naturschutz und Landschaftsplanung 46, 336-344

Macke, S. \& B. Schweppe-Kraft 2011. Ökonomisches Denken für den Naturschutz - ein Plädoyer für gemeinsame Argumente (Economic thinking for nature conservation - a call for common arguments). Natur und Landschaft, 86, 146-147.

Martin-López, B.; Montes, C. \& J. Benayas 2007. Influence of user characteristics on valuation of ecosystem services in Donana Natural Protected Area (south-western Spain). Environmental Conservation 34, 215-224.
Mayer, M. 2014. Can nature-based tourism benefits compensate for the costs of national parks? A Study of the Bavarian Forest National Park, Germany. Journal of Sustainable Tourism 22, 561583.

Mayer, M. \& H. Job 2014. The economics of protected areas - a European perspective. Zeitschrift für Wirtschaftsgeographie 58, 73-97.

Meyerhoff, J.; Angeli, D. \& V. Hartje 2010. Valuing the benefits of implementing a national strategy on biological diversity. The case study of Germany. Environ Science \& Policy 23, 109-119.

Mmopelwa, G.; Kgathi, D.L. \& L. Molefhe. 2007. Tourists' perceptions and their willingness to pay for park fees: a case study of self-drive tourists and clients for mobile tour operators in Moremi Game Reserve, Botswana. Tourism Management 28, 1044-1056.

Molnarová, K.; Sklenicka, P.; Stiborek, J.; Svobodová, K.; Šalek, M. \& E. Brabec 2012. Visual preferences for wind turbines: Location, numbers and respondent characteristics. Applied Energy 92, 269-278.

Müller, M. \& H. Job 2009. Managing natural disturbance in protected areas: Tourists' attitude towards the bark beetle in a German national park. Biological Conservation 142, 375-383.

Oom do Valle, P.; Pintassilgo, P.; Matias, A. \& F. André 2012. Tourist attitudes towards an accommodation tax earmarked for environmental protection: A survey in the Algarve. Tourism Management 33, 1408-1416.

Petrosillo, I.; Zurlini, G.; Corliano, M.E.; Zaccarelli, N. \& M. Dadamo 2007. Tourist perception of recreational environment and management in a marine protected area. Landscape and Urban Planning 79, 29-37. 
Pickering, C. \& A. Barros 2013. Mountain environments and tourism. In: Holden, A. \& D.A. Fennell (eds.): The Routledge Handbook of Tourism and the Environment. Routledge; London et al.; pp. 183-191.

Pröbstl-Haider, U. \& W. Haider 2014. The role of protected areas in destination choice in the European Alps. Zeitschrift für Wirtschaftsgeographie 58, 144-163.

Radford, K.G. \& P. James 2013. Changes in the value of ecosystem services along a rural-urban gradient: A case study of Greater Manchester, UK. Landscape and Urban Planning 109, 117-127.

Renner, C.; Lupp, G.; Stein, C.; Siegrist, D. \& O. Bastian 2012. Maintaining high biodiversity and landscape diversity for and through tourism - approaches for co-financing models. In: Fredman, P. et al. (eds.): Proc 6th Int Conf "Monitoring and management of visitors in recreational and protected areas. Outdoor recreation in change - Current knowledge and future challenges, Stockholm", Sweden, 21.-24.8. 2012. (Forskningsprogrammet Friluftsliv i förändring Rapport 19), pp. 188-189

Reynisdottir, M.; Song, H. \& J. Agrusa 2008. Willingness to pay entrance fees to natural attractions: An Icelandic case study. Tourism Management 29, 1076-1083.

Riera, P.; Signorello, G.; Thiene, M.; Mahieu, P.-A.; Navrud, S.; Kaval, P.; Rulleau, B.; Mavsar, R.;

Madureira, L.; Meyerhoff, J.; Elsasser, P.; Notarol, S.; De Salvo, M.; Giergiczny, M. \& S. Dragoi 2012. Non-market valuation of forest goods and services: Good practice guidelines. Journal of Forest Economics 18, 259-270.

Rosenberger, R.S.; Needham, M.D.; Morzillo, A.T. \& C. Moehrke 2012. Attitudes, willingness to pay, and stated values for recreation use fees at an urban proximate forest. Journal of Forest Economics 18, 271-281.
Schulze, G. 1997. Die Erlebnisgesellschaft: Kultursoziologie der Gegenwart. (The adventure society: cultural sociology in the present). Campus: Frankfurt - New York. 7th ed.

Schweppe-Kraft, B. 2009. Natural capital in Germany - State and valuation; with special reference to biodiversity. In: Döring, R. (ed.). Sustainability, natural capital and nature conservation. Marburg; $24 \mathrm{pp}$.

Schweppe-Kraft, B. \& K. Grunewald (2014). Approaches to the economic valuation of natural assets. In: Grunewald, K. \& O. Bastian (eds.). Ecosystem Services: Concept, Methods and Case Studies (pp. 90-109). Heidelberg, Berlin: Springer.

Seppelt, R.; Fath, B.; Burkhard, B.; Fisher, J.L.; GrêtRegamey, A.; Lautenbach, S.; Pert, P.; Hotes, S.; Spangenberg, J.; Verburg, P.H. \& A.P.E. van Oudenhoven 2012. Form follows function? Proposing a blueprint for ecosystem service assessments based on reviews and case studies. Ecological Indicators 21, 145-154.

SfZ 2014. Tourismusanalyse 2014. (Tourism analysis 2014). Stiftung für Zukunftsfragen; Hamburg.

Spangenberg, J.H. \& J. Settele 2010. Precisely incorrect?Monetising the value of ecosystem services. Ecological Complexity 7, 327-337.

Strasdas, W. 2006. The global market for nature-based tourism. In: Job, H. \& J. Li (eds.): Natural heritage, ecotourism and sustainable development (pp. 55-64). Lassleben; Kallmünz.

Tacconi, L. 2012. Redefining payments for environmental services. Ecological Economics 73, 29-36.

Termorshuizen, J.W. \& P. Opdam 2009. Landscape services as a bridge between landscape ecology and sustainable development. Landscape Ecology 24, 1037-1052. 
TIES 1990. About ecotourism: Definitions \& principles. The International Ecotourism Society. https://www.ecotourism.org/what-is-ecotourism (Date: 4.10.2014).

Tisdell, C. 2006. Valuation of tourism's natural resource. In: Dwyer, L. \& P. Forsyth (eds.): International Handbook on the Economics of Tourism. Edward Elgar; Cheltenham Northhampton; pp. 359-378.

UBA 2007. Ökonomische Bewertung von Umweltschäden. (Economic assessment of environmental damages). German Federal Environment Agency. Dessau.

UBA2009. Umweltbewusstseinund Umweltverhalten der sozialen Milieus in Deutschland. (Environmental awareness and environmental behavior of social milieus in Germany). German Federal Environment Agency. Dessau.

Wang, P. \& J. Jia 2012. Tourists' willingness to pay for biodiversity conservation and environment protection, Dalai Lake protected area: implications for entrance fee and sustainable management. Ocean \& Coastal Management 62, 24-33.

Yadav, L.P. \& S. O'Neill 2013. Is there agreement between beneficiaries on who should bear the costs of conserving farm landscapes? Tourism Management 39, 62-70. 